\title{
Detection of somatic mutations in the mitochondrial DNA control region D-loop in brain tumors: The first report in Malaysian patients
}

\author{
ABDUL AZIZ MOHAMED YUSOFF ${ }^{1}$, KHAIROL NAAIM MOHD NASIR ${ }^{1}$, \\ KHALILAH HARIS ${ }^{1}$, SITI ZULAIKHA NASHWA MOHD KHAIR ${ }^{1}$, \\ ABDUL RAHMAN IZAINI ABDUL GHANI ${ }^{1}$, ZAMZURI IDRIS ${ }^{1,2}$ and JAFRI MALIN ABDULLAH ${ }^{1,2}$ \\ ${ }^{1}$ Department of Neurosciences, School of Medical Sciences; ${ }^{2}$ Center for Neuroscience Services and \\ Research, Universiti Sains Malaysia, Health Campus, Kubang Kerian, Kelantan 16150, Malaysia
}

Received September 20, 2015; Accepted May 11, 2017

DOI: $10.3892 / 01.2017 .6851$

\begin{abstract}
Although the role of nuclear-encoded gene alterations has been well documented in brain tumor development, the involvement of the mitochondrial genome in brain tumorigenesis has not yet been fully elucidated and remains controversial. The present study aimed to identify mutations in the mitochondrial DNA (mtDNA) control region D-loop in patients with brain tumors in Malaysia. A mutation analysis was performed in which DNA was extracted from paired tumor tissue and blood samples obtained from 49 patients with brain tumors. The D-loop region DNA was amplified using the PCR technique, and genetic data from DNA sequencing analyses were compared with the published revised Cambridge sequence to identify somatic mutations. Among the 49 brain tumor tissue samples evaluated, 25 cases $(51 \%)$ had somatic mutations of the mtDNA D-loop, with a total of 48 mutations. Novel mutations that had not previously been identified in the D-loop region (176 A-deletion, $476 \mathrm{C}>\mathrm{A}, 566 \mathrm{C}>\mathrm{A}$ and 16405 A-deletion) were also classified. No significant associations between the D-loop mutation status and the clinicopathological parameters were observed. To the best of our knowledge, the current study presents the first evidence of alterations in the mtDNA D-loop regions in the brain tumors of Malaysian patients. These results may provide an overview and data regarding the incidence of mitochondrial genome alterations in Malaysian patients with brain tumors. In addition to nuclear genome aberrations, these specific mitochondrial
\end{abstract}

Correspondence to: Dr Abdul Aziz Mohamed Yusoff, Department of Neurosciences, School of Medical Sciences, Universiti Sains Malaysia, Health Campus, Jalan Raja Perempuan Zainab II, Kubang Kerian, Kelantan 16150, Malaysia

E-mail: azizmdy@yahoo.com

Key words: mitochondrial DNA, D-loop, somatic mutation, brain tumors, Malaysian patients genome alterations may also be considered as potential cancer biomarkers for the diagnosis and staging of brain cancers.

\section{Introduction}

Brain and central nervous system (CNS) tumors are the second most common type of cancer in children, comprising $21 \%$ of cases, and the third most common cancer type in adolescents, contributing to $\sim 10 \%$ of cases (1). It is estimated that $>23,800$ (13,450 males and 10,350 females) new cases of brain and CNS tumors will be diagnosed and 16,700 (9,620 men and 7,080 women) brain and CNS tumor-associated mortalities will occur in the United States in 2017 (http://www.cancer.org) $(2,3)$. The incidence of brain tumors in Malaysia was relatively low, accounting for $\sim 1.95 \%$ of all cancer cases prior to 2003 (4). Since then, the incidence rate has been increasing rapidly, and brain and CNS tumors have become the third most common type of pediatric cancer in Malaysia, behind leukemia and lymphoma $(5,6)$. In 2012, the incidence rate was 4.6/100,000 individuals/year (6).

The overall prognosis for brain tumors is based on tumor pathology or grade $(7,8)$. The majority of patients who are diagnosed with malignant primary brain tumors have a poor prognosis $(7,8)$. Therefore, it is crucial to identify novel potential bio-tumor markers for brain tumors in order to improve the diagnosis, prognosis and treatment of the disease.

Mitochondria have long been considered as crucial organelles, since they contain their own DNA (9). Prior research shows that mitochondria have a variety of roles in energy metabolism and cellular homeostasis, including ATP production, reactive oxygen species (ROS) production, metabolic homeostasis and apoptosis $(10,11)$. Human mitochondrial DNA (mtDNA) is a closed circular, double-stranded molecule of $\sim 16.5 \mathrm{~kb}$ (12). It contains genes coding for 13 polypeptide components of respiratory chain enzyme complexes (complex I, III, IV and V), two ribosomal RNAs (rRNAs) and 22 transfer RNAs (tRNAs), which are components of the mitochondrial protein translation system $(12,13)$. mtDNA is also composed of a non-coding region known as the displacement-loop (D-loop), located between nucleotides 16,024 and 576, which contain 
essential elements that are responsible for the transcription and replication of the mitochondrial genome (14). Furthermore, mtDNA is considered to have a much higher mutation rate than nuclear DNA and is more sensitive to oxidative damage (15). As mtDNA is in close proximity to the respiratory chain, it is constantly exposed to endogenous ROS produced by the mitochondria that can damage DNA (16).

The first report of mtDNA mutations was described in 1998 by Polyak et al (17) in human colorectal cancer. Since then, numerous studies have been reported with $>200$ mtDNA mutation and/or alteration cases in cancer published worldwide $(18,19)$. Somatic mutations of mtDNA have been identified in multiple cancer types, including breast cancer, colorectal cancer, hepatocellular carcinoma, gastric cancer and lung cancer (19-24). Therefore, mtDNA is considered to serve an important role in tumor progression and carcinogenesis. The mtDNA D-loop has been identified as a hot spot of genetic alterations in human cancer (25-27). Accumulation of mtDNA D-loop alterations may contribute to altered replication and/or transcription of mitochondrial genes, which may lead to mitochondrial dysfunction and excessive cellular ROS production.

Although there have been several alterations in mtDNA reported in patients with brain tumors (28-30), the contribution of mtDNA mutations to brain tumorigenesis remains unclear and requires additional exploration. As data on mtDNA alterations was not available for Malaysian patients with brain tumors, the D-loop mtDNA alterations were examined in patients with brain tumors of diverse types and grades. The aims of the present study were to identify mtDNA D-loop alterations, and to assess their association with clinicopathological features of brain tumors.

\section{Materials and methods}

Tumor specimens. Paired samples of brain tumor tissue and blood samples from 49 patients were collected during elective neurosurgical procedures at the Department of Neurosciences, Hospital Universiti Sains Malaysia, Kubang Kerian, Kelantan, Malaysia between July 2010 and December 2014. Peripheral blood specimens were obtained from the same patients as a the control. The study population consisted of 29 males (59.2\%) and 20 females $(40.8 \%)$ with age of patients ranging between 2 and 74 years (mean, 44.2 years). The histopathological diagnosis of the brain tumor samples was determined according to the World Health Organization (WHO) criteria (31) by a consultant neuropathologist. These neoplasms comprised 6 pilocytic astrocytoma WHO grade I (PA), 2 astrocytoma WHO grade II (A II), 5 anaplastic astrocytoma WHO grade III (AA III), 16 glioblastoma multiforme WHO grade IV (GBM IV), 3 oligodendroglioma WHO grade II (ODG), 2 ependymoma WHO grade II (EP) and 15 meningioma WHO grade I. The protocol was approved by the Research Ethics Committee of Universiti Sains Malaysia, and all patients provided written informed consent for participation. The tumor tissue biopsies and peripheral blood specimens $(5 \mathrm{ml})$, obtained from all patients, were snap-frozen in liquid nitrogen and stored at $-80^{\circ} \mathrm{C}$ until DNA extraction.

DNA extraction. Genomic DNA was extracted from brain tumor tissues and blood samples of patients using the QIAamp
DNA mini kit (Qiagen GmbH, Hilden, Germany), according to the manufacturer's protocol. The concentration and quality of extracted DNA was measured using a NanoDrop ND1000 spectrophotometer (NanoDrop; Thermo Fisher Scientific, Inc., Pittsburgh, PA, USA) and 1\% agarose gel electrophoresis stained with $10 \mathrm{mg} / \mathrm{ml}$ ethidium bromide (Invitrogen; Thermo Fisher Scientific, Inc.).

Polymerase chain reaction (PCR) amplification of the $m t D N A$ $D$-loop. Three sets of primers were designed to amplify or target three independent but overlapping fragments that span the whole D-loop region, as listed in Table I. Briefly, PCR was performed on the SureCycler 8800 Thermal Cycler (Agilent Technologies, Inc., Santa Clara, CA, USA), in a $50 \mu 1$ reaction mixture containing $100 \mathrm{ng}$ DNA template, $200 \mu \mathrm{M}$ each dNTP, 20 pMol each primer, $10 \mu 1$ 5X Phusion HF buffer (Thermo Fisher Scientific, Inc.) and 2 U Phusion high-fidelity DNA polymerase (Thermo Fisher Scientific, Inc.).

The cycling profile was set at $98^{\circ} \mathrm{C}$ initial denaturation for $1 \mathrm{~min}$, followed by 35 cycles of denaturation at $98^{\circ} \mathrm{C}$ for $20 \mathrm{sec}$, annealing at $56^{\circ} \mathrm{C}$ for $20 \mathrm{sec}$, extension at $72^{\circ} \mathrm{C}$ for $20 \mathrm{sec}$ and a final extension at $72^{\circ} \mathrm{C}$ for $5 \mathrm{~min}$. The amplified PCR fragments were analyzed via $2 \%$ agarose gel electrophoresis using a GeneRuler 100 bp DNA ladder (Thermo Fisher Scientific, Inc.) in order to determine the expected size of the amplified PCR fragments. The PCR products with the expected size were purified with the QIAquick PCR Purification kit (Qiagen $\mathrm{GmbH}$ ) according to the manufacturer's protocol and stored at $-20^{\circ} \mathrm{C}$ until use for DNA sequencing analysis.

Direct sequencing of the mtDNA D-loop. Purified PCR products were sequenced in both directions using the same primers as described for the PCR reactions (Table I). Sequencing was performed using a Big Dye Terminator cycle sequencing kit (Applied Biosystems; Thermo Fisher Scientific, Inc.) according to the manufacturer's instructions, on an ABI Prism 3700 DNA Analyzer automated sequencer (Applied Biosystems; Thermo Fisher Scientific, Inc.). DNA sequencing and electropherogram results were analyzed manually and aligned using BLAST software from the NCBI site (http://www.ncbi.nlm.nih.gov/blast), and then compared with the published revised Cambridge Reference Sequence (rCRS) of the human mtDNA (NC_012920) in the MITOMAP database (www.mitomap.org).

Statistical analysis. The data were analyzed using GraphPad Prism software version 5 (GraphPad Software, Inc., La Jolla, CA, USA) with Fisher's exact test to calculate the significance of associations between mtDNA D-loop mutations and the clinicopathological parameters of brain tumor samples. $\mathrm{P}<0.05$ was considered to indicate a statistically significant difference.

\section{Results}

Patient characteristics. Brain tumor tissue specimens from 49 Malaysian patients were obtained at the same time as blood samples, which were used as controls. If the mtDNA sequence in the tumor differed from the corresponding blood sample, this was described as a somatic mutation. The mean age of the patients at the time of initial surgery was 44.2 years 
Table I. Polymerase chain reaction primers and the expected sizes of amplicons.

\begin{tabular}{llll}
\hline Primer & \multicolumn{1}{c}{ Forward primer, 5'-3' } & \multicolumn{1}{c}{ Reverse primer, 5'-3' } & \multicolumn{1}{c}{ Band size, bp } \\
\hline Mito-D-loop 1 & 5'-CCTATGTCGCAGTATCTGTC-3' & 5'-TGCTTTGAGGAGGTAAGCTA-3' $^{\text {4991 bp (np. 113-603) }}$ \\
Mito-D-loop 2 & 5'-GTCTTGTAAACCGGAGATGA-3' & 5'-GAGCGAGGAGAGTAGCAC-3' & 539 bp (np. 15,915-16,453) ${ }^{\mathrm{a}}$ \\
Mito-D-loop 3 & 5'-TACAGTCAAATCCCTTCTCG-3' & 5'-AATAGGATGAGGCAGGAATC-3' & 383 bp (np. 16,342-155)
\end{tabular}

${ }^{\text {an }}$ ucleotide position according to the revised Cambridge Reference Sequence (NC_012920).

(range, 2-74 years). Of these, 29 were males (59.2\%) and 20 were females $(40.8 \%)$. In this retrospective cohort, GBM IV represents $32.7 \%(n=16)$ of all primary brain tumors, followed by meningioma $(n=15,30.6 \%)$, PA I $(n=6,12.2 \%)$, AA III $(n=5,10.2 \%)$, ODG $(n=3,6.1 \%)$, A II $(n=2,4.1 \%)$ and EP $(n=2$, $4.1 \%)$

Somatic mtDNA D-loop mutations status in brain tumors. A total of three overlapping fragments that spanned the whole 1,122 bp D-loop region were amplified in 49 brain tumor tissue samples and corresponding blood samples. The successful amplification of three fragments resulted in the amplified fragments of sizes 383, 491 and 539 bp (Fig. 1) (the total size of amplified fragments was $1,413 \mathrm{bp}, 79 \%$ more than the entire D-loop due to the overlapping regions). Amplified fragments/products were then sequenced, and the sequenced data obtained were compared with the rCRS in the MITOMAP database.

By analyzing the sequencing data, it was observed that $51 \%$ (25/49) of the patients carried a total of 48 somatic mutations at 27 positions in the D-loop of mtDNA (Table II). Among these mutations, four (176 A-deletion, 476C $>\mathrm{A}, 566 \mathrm{C}>\mathrm{A}$ and 16405 A-deletion) had not previously been recorded in the MITOMAP database (Fig. 2). Therefore, it was assumed that they are novel mutations. Mutations in nucleotide $195 \mathrm{~T}>\mathrm{C}$, 146T >C, 152 T>C, 204 T>C, 303 CC- insertion, 311 C- insertion and $16519 \mathrm{~T}>\mathrm{C}$ were also found, which have previously been reported in brain tumors $(28,29,32)$. In addition, $94 \%$ $(45 / 48)$ of these mutations were homoplasmic and 19\% (9/48) of them were located in the D310 mononucleotide repeat (np 303-315). Representative DNA sequence chromatograms are presented in Fig. 2.

mtDNA D-loop polymorphism status in brain tumors. Any DNA sequence variation present in the peripheral blood and tumor tissue of patients was classified as a polymorphism. In the present study, 210 polymorphisms were identified at 26 nucleotide positions (Table III). The majority of polymorphisms identified in the present study were found in the nucleotides $263 \mathrm{~A}>\mathrm{G}, 16189 \mathrm{~T}>\mathrm{C}, 16261 \mathrm{C}>\mathrm{T}$ and $16271 \mathrm{~T}>\mathrm{C}$.

Associations between D-loop mutation status and clinicopathological parameters of brain tumors. Table IV describes the D-loop mutation status and its association with patient gender, age, race and histological tumor type. No significant association was observed between the D-loop mutation status and gender $(\mathrm{P}=1.0)$; however, the number of patients with

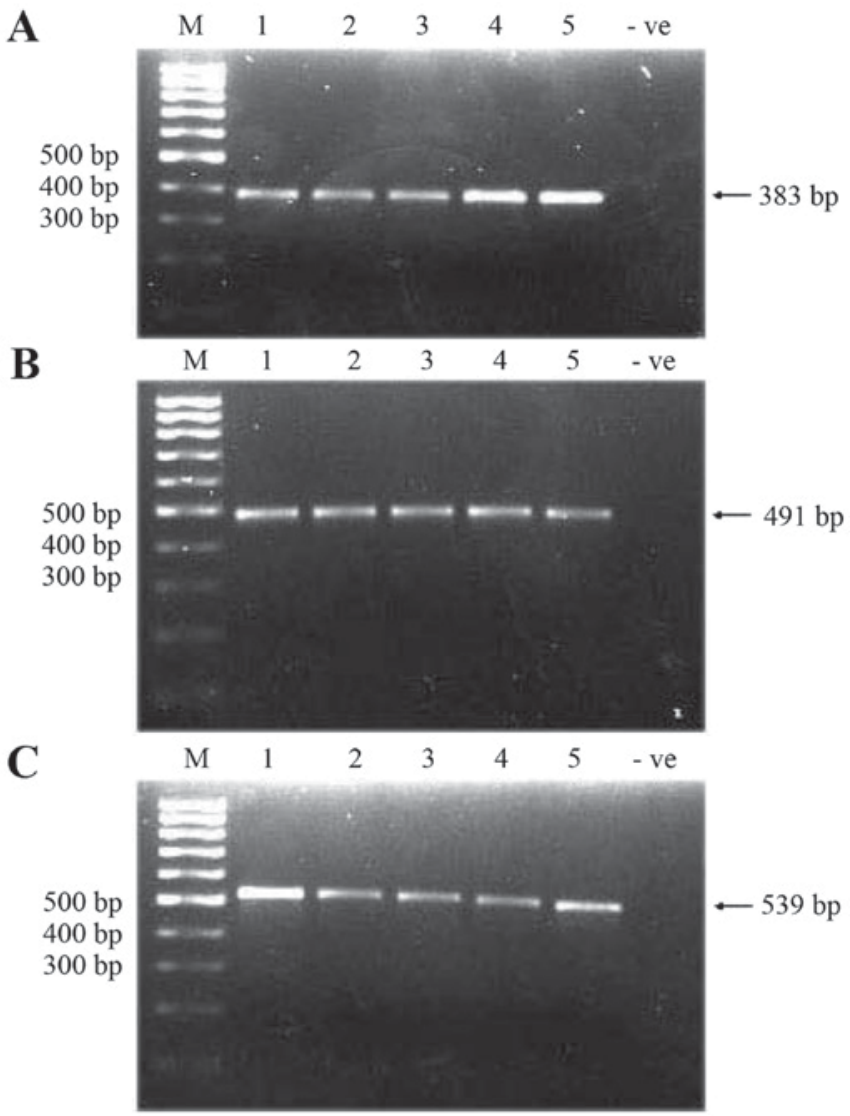

Figure 1. Polymerase chain reaction amplification of three overlapping fragments of mtDNA D-loop region using the designed primers. (A) Fragment size of $383 \mathrm{bp}$; (B) fragment size of $491 \mathrm{bp}$; (C) fragment size of $539 \mathrm{bp}$. Lane $1-5$, tumor tissues. -ve, negative control $\left(\mathrm{H}_{2} \mathrm{O}\right)$; $\mathrm{M}$, molecular weight marker (100 bp); mt, mitochondrial.

D-loop mutations tends to be higher in males $(n=15 / 25,60 \%)$ than females $(n=10 / 25,40 \%)$.

In the $<45$ and $\geq 45$ year groups, the association was determined to be non-significant, although D-loop mutations were observed to be more evident in the $\geq 45$ year group $(n=18 / 25$, $72 \%$ ) compared with in the $<45$ year group $(n=7 / 25,28 \%)$. In addition, mutations of the D-loop had no significant association with the ethnicity of patients.

As presented in Table IV, the D-loop mutations were frequent in GBM IV $(n=12 / 25,48 \%)$, followed by distribution in meningioma $(n=8 / 25,32 \%)$, and equal in PA I and AA III $(n=2 / 25,8 \%)$. Furthermore, no significant association between D-loop mutations and any of these histological tumor types was observed. 
Table II. Mitochondrial DNA D-loop somatic mutations in patients with brain tumors.

\begin{tabular}{|c|c|c|c|c|c|c|}
\hline $\begin{array}{l}\text { Patient } \\
\text { code }\end{array}$ & $\begin{array}{l}\text { Tumor } \\
\text { type }\end{array}$ & $\begin{array}{l}\text { Nucleotide } \\
\text { position }\end{array}$ & $\begin{array}{l}\text { Somatic } \\
\text { mutation }\end{array}$ & $\begin{array}{l}\text { Homoplasmy/ } \\
\text { heteroplasmy }\end{array}$ & $\begin{array}{l}\text { Novel/ } \\
\text { reported }\end{array}$ & (Refs.) \\
\hline ID003 & GBM IV & 16265 & $A-G$ & Homoplasmy & $\begin{array}{l}\text { Bladder } \\
\text { Leukemia } \\
\text { Prostate cancer }\end{array}$ & $\begin{array}{l}(33) \\
(34) \\
(35)\end{array}$ \\
\hline ID004 & GBM IV & $\begin{array}{l}414 \\
476^{\mathrm{a}}\end{array}$ & $\begin{array}{c}\mathrm{T}-\mathrm{G} \\
\mathrm{C}-\mathrm{A} / \mathrm{C}\end{array}$ & $\begin{array}{l}\text { Homoplasmy } \\
\text { Heteroplasmy }\end{array}$ & $\begin{array}{l}\text { Brain tumor } \\
\text { Gastric cancer } \\
\text { Breast } \\
\text { Oral } \\
\text { Colorectal } \\
\text { Novel }^{\text {a }}\end{array}$ & $\begin{array}{c}(32) \\
(36) \\
(37) \\
(38 \\
(39) \\
\text { Present study }\end{array}$ \\
\hline ID005 & GBM IV & 195 & $\mathrm{~T}-\mathrm{C}$ & Homoplasmy & $\begin{array}{l}\text { Brain tumor } \\
\text { Ovarian } \\
\text { Breast } \\
\text { Leukemia }\end{array}$ & $\begin{array}{c}(28,29) \\
(40) \\
(41) \\
(42)\end{array}$ \\
\hline ID006 & AA III & 16356 & $\mathrm{~T}-\mathrm{C}$ & Homoplasmy & $\begin{array}{l}\text { Brain tumor } \\
\text { Breast }\end{array}$ & $\begin{array}{l}(28) \\
(41)\end{array}$ \\
\hline ID007 & Meningioma I & 249 & A deletion & Homoplasmy & $\begin{array}{l}\text { Nasopharyngeal } \\
\text { carcinoma } \\
\text { Breast } \\
\text { Prostate cancer }\end{array}$ & $\begin{array}{l}(43) \\
(44) \\
\left(35^{\mathrm{a}}\right)\end{array}$ \\
\hline & & 73 & A-G & Homoplasmy & $\begin{array}{l}\text { Prostate cancer } \\
\text { Brain tumor } \\
\text { Breast } \\
\text { Leukemia }\end{array}$ & $\begin{array}{l}(45) \\
(29) \\
(41) \\
(42)\end{array}$ \\
\hline ID008 & GBM IV & 249 & A deletion & Homoplasmy & $\begin{array}{l}\text { Nasopharyngeal } \\
\text { carcinoma } \\
\text { Breast } \\
\text { Prostate }\end{array}$ & $\begin{array}{l}(43) \\
(44) \\
\left(35^{\mathrm{a}}\right)\end{array}$ \\
\hline & & 311 & $\mathrm{C}$ insertion & Homoplasmy & $\begin{array}{l}\text { Brain tumor } \\
\text { Breast } \\
\text { Leukemia }\end{array}$ & $\begin{array}{l}(32) \\
(37) \\
(42)\end{array}$ \\
\hline & & 73 & $A-G$ & Homoplasmy & $\begin{array}{l}\text { Prostate cancer } \\
\text { Brain tumor } \\
\text { Breast } \\
\text { Leukemia }\end{array}$ & $\begin{array}{l}(45) \\
(29) \\
(41) \\
(42)\end{array}$ \\
\hline & & 16356 & $\mathrm{~T}-\mathrm{C}$ & Homoplasmy & $\begin{array}{l}\text { Brain tumor } \\
\text { Breast }\end{array}$ & $\begin{array}{l}(28) \\
(41)\end{array}$ \\
\hline ID011 & PA & 303 & C insertion & Homoplasmy & $\begin{array}{l}\text { Brain tumor } \\
\text { Gastric cancer } \\
\text { Breast } \\
\text { Oral }\end{array}$ & $\begin{array}{l}(32) \\
(36) \\
(37) \\
(38)\end{array}$ \\
\hline & & 311 & $\mathrm{C}$ insertion & Homoplasmy & $\begin{array}{l}\text { Brain tumor } \\
\text { Breast } \\
\text { Leukemia }\end{array}$ & $\begin{array}{l}(32) \\
(37) \\
(42)\end{array}$ \\
\hline ID013 & PA & 16325 & $\mathrm{~T}-\mathrm{C}$ & Homoplasmy & $\begin{array}{l}\text { Brain tumor } \\
\text { Leukemia } \\
\text { Breast }\end{array}$ & $\begin{array}{l}(32) \\
(34) \\
(37)\end{array}$ \\
\hline ID014 & AA III & 249 & A deletion & Homoplasmy & $\begin{array}{l}\text { Nasopharyngeal } \\
\text { carcinoma } \\
\text { Breast } \\
\text { Prostate }\end{array}$ & $\begin{array}{l}(43) \\
(44) \\
\left(35^{\mathrm{a}}\right)\end{array}$ \\
\hline & & 311 & C insertion & Homoplasmy & $\begin{array}{l}\text { Brain tumor } \\
\text { Breast } \\
\text { Leukemia }\end{array}$ & $\begin{array}{l}(32) \\
(37) \\
(42)\end{array}$ \\
\hline
\end{tabular}


Table II. Continued.

\begin{tabular}{|c|c|c|c|c|c|c|}
\hline $\begin{array}{l}\text { Patient } \\
\text { code }\end{array}$ & $\begin{array}{l}\text { Tumor } \\
\text { type }\end{array}$ & $\begin{array}{c}\text { Nucleotide } \\
\text { position }\end{array}$ & $\begin{array}{l}\text { Somatic } \\
\text { mutation }\end{array}$ & $\begin{array}{l}\text { Homoplasmy/ } \\
\text { heteroplasmy }\end{array}$ & $\begin{array}{l}\text { Novel/ } \\
\text { reported }\end{array}$ & (Refs.) \\
\hline \multirow[t]{4}{*}{ ID017 } & GBM IV & 311 & $\mathrm{C}$ insertion & Homoplasmy & Brain tumor & (32) \\
\hline & & & & & Breast & (37) \\
\hline & & & & & Leukemia & $(42)$ \\
\hline & & 511 & $\mathrm{C}-\mathrm{T}$ & Homoplasmy & Cervical cancer & $(46)$ \\
\hline \multirow[t]{11}{*}{ ID019 } & Meningioma I & 146 & $\mathrm{~T}-\mathrm{C}$ & Homoplasmy & Brain tumor & $(29)$ \\
\hline & & & & & Breast & $(37)$ \\
\hline & & & & & Leukemia & $(42)$ \\
\hline & & & & & Oral & $(38)$ \\
\hline & & 204 & $\mathrm{~T}-\mathrm{C}$ & Homoplasmy & Brain tumor & $(28)$ \\
\hline & & & & & Ovarian & $(47)$ \\
\hline & & & & & Leukemia & $(34,42)$ \\
\hline & & 16519 & $\mathrm{~T}-\mathrm{C}$ & Homoplasmy & Brain tumor & (28) \\
\hline & & & & & Leukemia & (34) \\
\hline & & & & & Gastric cancer & (36) \\
\hline & & & & & Breast & (41) \\
\hline \multirow[t]{10}{*}{ ID020 } & GBM IV & 195 & $\mathrm{~T}-\mathrm{C}$ & Homoplasmy & Brain tumor & $(28,29)$ \\
\hline & & & & & Ovarian & (40) \\
\hline & & & & & Breast & (41) \\
\hline & & & & & Leukemia & $(42)$ \\
\hline & & 303 & $\mathrm{CC}$ insertion & Homoplasmy & Brain tumor & (32) \\
\hline & & & & & Gastric cancer & $(36)$ \\
\hline & & & & & Breast & (37) \\
\hline & & & & & Oral & (38) \\
\hline & & 411 & $\mathrm{C}-\mathrm{G} / \mathrm{C}$ & Heteroplasmy & Leukemia & (34) \\
\hline & & 16381 & $\mathrm{~T}-\mathrm{C}$ & Homoplasmy & Reported in MITOMAP & MITOMAP \\
\hline \multirow[t]{4}{*}{ ID021 } & Meningioma I & $176^{\mathrm{a}}$ & A deletion & Homoplasmy & Novel $^{\mathrm{a}}$ & Present study \\
\hline & & 16265 & $A-G$ & Homoplasmy & Bladder & $(33)$ \\
\hline & & & & & Leukemia & (34) \\
\hline & & & & & Prostate cancer & $(35)$ \\
\hline \multirow[t]{3}{*}{ ID022 } & Meningioma I & 411 & $\mathrm{C}-\mathrm{G}$ & Homoplasmy & Leukemia & $(34)$ \\
\hline & & 432 & $\mathrm{~A}-\mathrm{C}$ & Homoplasmy & Reported in MITOMAP & \\
\hline & MITOMAP & & & & & \\
\hline ID024 & GBM IV & 186 & $\mathrm{C}-\mathrm{G}$ & Homoplasmy & Oral cancer & $(48)$ \\
\hline \multirow[t]{4}{*}{ ID026 } & GBM IV & 71 & G deletion & Homoplasmy & Oral cancer & $(49)$ \\
\hline & & 311 & $\mathrm{C}$ insertion & Homoplasmy & Brain tumor & $(32)$ \\
\hline & & & & & Breast & $(37)$ \\
\hline & & & & & Leukemia & $(42)$ \\
\hline \multirow[t]{3}{*}{ ID027 } & GBM IV & 61 & $\mathrm{C}-\mathrm{A}$ & Homoplasmy & Reported in MITOMAP & MITOMAP \\
\hline & & 16381 & $\mathrm{~T}-\mathrm{C}$ & Homoplasmy & Reported in MITOMAP & MITOMAP \\
\hline & & $16405^{\mathrm{a}}$ & A deletion & Homoplasmy & Novel $^{\mathrm{a}}$ & Present study \\
\hline \multirow[t]{4}{*}{ ID030 } & GBM IV & 311 & $\mathrm{C}$ insertion & Homoplasmy & Brain tumor & $(32)$ \\
\hline & & & & & Breast & $(37)$ \\
\hline & & & & & Leukemia & $(42)$ \\
\hline & & $523-524$ & AC deletion & Homoplasmy & Reported in MITOMAP & MITOMAP \\
\hline \multirow[t]{2}{*}{ ID036 } & Meningioma I & 503 & $A-G$ & Homoplasmy & Reported in MITOMAP & MITOMAP \\
\hline & & $566^{\mathrm{a}}$ & C-A & Homoplasmy & Novel $^{\mathrm{a}}$ & Present study \\
\hline \multirow[t]{7}{*}{ ID038 } & Meningioma I & 146 & $\mathrm{~T}-\mathrm{C}$ & Homoplasmy & Brain tumor & $(29)$ \\
\hline & & & & & Breast & $(37)$ \\
\hline & & & & & Leukemia & $(42)$ \\
\hline & & & & & Oral & (38) \\
\hline & & 152 & $\mathrm{~T}-\mathrm{C} / \mathrm{T}$ & Heteroplasmy & Brain tumor & $(29)$ \\
\hline & & & & & Breast & $(20,41)$ \\
\hline & & & & & Laryngeal & $(50)$ \\
\hline
\end{tabular}


Table II. Continued.

\begin{tabular}{|c|c|c|c|c|c|c|}
\hline $\begin{array}{l}\text { Patient } \\
\text { code }\end{array}$ & $\begin{array}{l}\text { Tumor } \\
\text { type }\end{array}$ & $\begin{array}{c}\text { Nucleotide } \\
\text { position }\end{array}$ & $\begin{array}{l}\text { Somatic } \\
\text { mutation }\end{array}$ & $\begin{array}{l}\text { Homoplasmy/ } \\
\text { heteroplasmy }\end{array}$ & $\begin{array}{l}\text { Novel/ } \\
\text { reported }\end{array}$ & (Refs.) \\
\hline ID039 & Meningioma I & 472 & $A-G$ & Homoplasmy & Reported in MITOMAP & MITOMAP \\
\hline ID042 & GBM IV & 16519 & $\mathrm{~T}-\mathrm{C}$ & Homoplasmy & $\begin{array}{l}\text { Brain tumor } \\
\text { Leukemia } \\
\text { Gastric cancer } \\
\text { Breast }\end{array}$ & $\begin{array}{l}(28) \\
(34) \\
(36) \\
(41)\end{array}$ \\
\hline ID044 & GBM IV & 146 & $\mathrm{~T}-\mathrm{C}$ & Homoplasmy & $\begin{array}{l}\text { Brain tumor } \\
\text { Breast } \\
\text { Leukemia } \\
\text { Oral }\end{array}$ & $\begin{array}{l}(29) \\
(37) \\
(42) \\
(38)\end{array}$ \\
\hline & & 204 & $\mathrm{~T}-\mathrm{C}$ & Homoplasmy & $\begin{array}{l}\text { Brain tumor } \\
\text { Ovarian } \\
\text { Leukemia }\end{array}$ & $\begin{array}{c}(28) \\
(47) \\
(34,42)\end{array}$ \\
\hline ID045 & Meningioma I & $176^{\mathrm{a}}$ & A deletion & Homoplasmy & Novel $^{\mathrm{a}}$ & Present study \\
\hline ID047 & Ependymoma & 16519 & $\mathrm{~T}-\mathrm{C}$ & Homoplasmy & $\begin{array}{l}\text { Brain tumor } \\
\text { Leukemia } \\
\text { Gastric cancer } \\
\text { Breast }\end{array}$ & $\begin{array}{l}(28) \\
(34) \\
(36) \\
(41)\end{array}$ \\
\hline
\end{tabular}

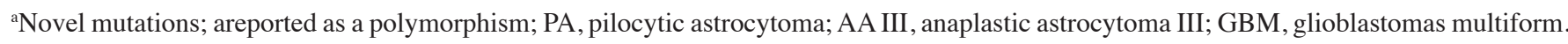

A $195 \mathrm{~T}>\mathrm{C}$

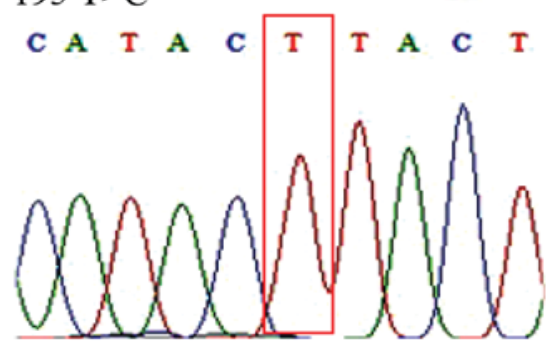

Normal (wild-type)

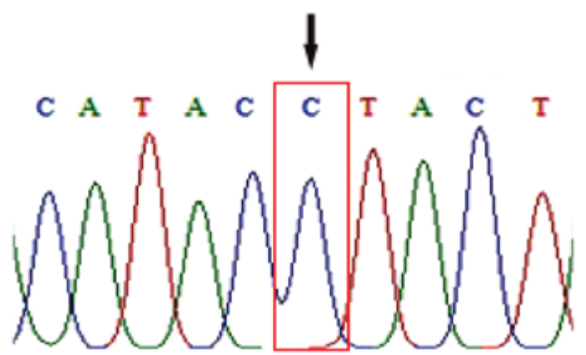

Tumor
B $476 \mathrm{C}>\mathrm{A}$

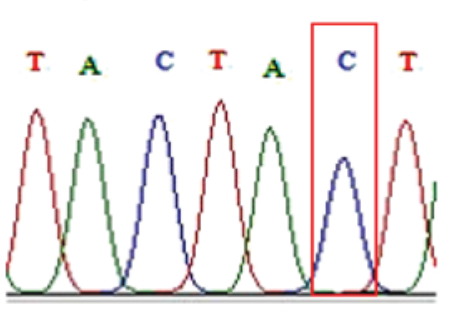

Normal (wild-type)

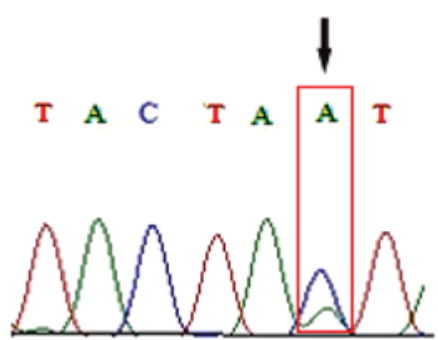

Tumor

Figure 2. Representative sequencing results depicting examples of mtDNA D-loop mutations in brain tumor tissue samples. (A) Chromatograms demonstrate a mutation of $\mathrm{T}$ to $\mathrm{C}$ transition at nucleotide position 195. (B) Novel heteroplasmic mutation of $\mathrm{C}$ to A transversion at nucleotide 476 . In the tumor sample, there are two peaks that represent a mixture of $\mathrm{C}$ and $\mathrm{A}$ nucleotides. Mt, mitochondrial.

\section{Discussion}

DNA mutation in mitochondria is one of the most common genetic alterations in cancer $(51,52)$ and has been widely investigated (51-53). mtDNA alterations were reported to be frequently activated via certain nucleotide changes in the control region that is known as the D-loop region $(17,18,54)$.
This area has been identified as a hot spot region for somatic mtDNA mutations in various types of human cancer, including breast, colorectal and lung cancer (55-58). Thus far, the majority of research on tumor-driving mutations and associated mutations in mtDNA has focused on alterations of the D-loop in the mitochondrial genome $(26,28,38)$. Lin et al $(38)$ detected somatic D-loop mutations in $62.5 \%$ patients with oral 
Table III. Mitochondrial DNA D-loop polymorphisms in patients with brain tumors.

\begin{tabular}{|c|c|c|}
\hline Nucleotide position & Base variation & Cases, $\mathrm{n}$ \\
\hline 143 & $\mathrm{G} \rightarrow \mathrm{A}$ & 2 \\
\hline 189 & $\mathrm{~A} \rightarrow \mathrm{G}$ & 1 \\
\hline 199 & $\mathrm{~T} \rightarrow \mathrm{C}$ & 3 \\
\hline 263 & $\mathrm{~A} \rightarrow \mathrm{G}$ & 20 \\
\hline 318 & $\mathrm{~T} \rightarrow \mathrm{C}$ & 3 \\
\hline 16093 & $\mathrm{~T} \rightarrow \mathrm{C}$ & 10 \\
\hline 16129 & $\mathrm{G} \rightarrow \mathrm{A}$ & 13 \\
\hline 16162 & $\mathrm{~A} \rightarrow \mathrm{G}$ & 11 \\
\hline 16172 & $\mathrm{~T} \rightarrow \mathrm{C}$ & 4 \\
\hline 16189 & $\mathrm{~T} \rightarrow \mathrm{C}$ & 23 \\
\hline 16223 & $\mathrm{C} \rightarrow \mathrm{T}$ & 12 \\
\hline 16256 & $\mathrm{C} \rightarrow \mathrm{T}$ & 10 \\
\hline 16259 & $\mathrm{~T} \rightarrow \mathrm{C}$ & 5 \\
\hline 16261 & $\mathrm{C} \rightarrow \mathrm{T}$ & 24 \\
\hline 16271 & $\mathrm{~T} \rightarrow \mathrm{C}$ & 19 \\
\hline 16278 & $\mathrm{C} \rightarrow \mathrm{T}$ & 5 \\
\hline 16288 & $\mathrm{~T} \rightarrow \mathrm{C}$ & 8 \\
\hline 16290 & $\mathrm{C} \rightarrow \mathrm{T}$ & 2 \\
\hline 16298 & $\mathrm{~T} \rightarrow \mathrm{C}$ & 2 \\
\hline 16304 & $\mathrm{~T} \rightarrow \mathrm{C}$ & 9 \\
\hline 16309 & $\mathrm{~A} \rightarrow \mathrm{G}$ & 5 \\
\hline 16311 & $\mathrm{~T} \rightarrow \mathrm{C}$ & 3 \\
\hline 16319 & $\mathrm{G} \rightarrow \mathrm{A}$ & 6 \\
\hline 16325 & $\mathrm{~T} \rightarrow \mathrm{C}$ & 2 \\
\hline 16362 & $\mathrm{~T} \rightarrow \mathrm{C}$ & 3 \\
\hline 16390 & $\mathrm{G} \rightarrow \mathrm{A}$ & 5 \\
\hline
\end{tabular}

squamous cell carcinoma. Rahmani et al (41) reported the presence of mtDNA D-loop mutations in 52\% patients with breast cancer. In cases of brain tumors, Montanini et al (59) identified sequence alterations in $36 \%$ of patients with malignant gliomas, primarily in the D-loop region.

Until now, there were no published studies or data available on mtDNA mutations in the brain tumors of Malaysian patients. As the majority of the available studies on mtDNA mutations in brain tumors were conducted on cohorts in Western countries, it was assumed that this is the first study involving Malaysian patients. In the current study, the frequency of mtDNA mutations was identified in $51 \%$ of the patients tested, which was high when compared with three prior studies of German patients with brain tumors: $41 \%$ glioblastoma (28), $43 \%$ neurofibromatosis type I (60) and 40\% medulloblastoma (61). However, this rate was lower than that reported for pilocytic astrocytoma (84\%) by Lueth et al (32). The difference in the frequency of mtDNA mutations may be due to sample size, or the genetic differences among the studied populations.

The majority of nucleotide changes reported in the present study have been previously described; mutations at nucleotide positions $303,311,146,152,204,16,356$ and 16,519 have been reported in patients with brain tumors $(28,29,32)$. All of these reported mutations were also observed in our brain tumor samples. In addition, changes in these nucleotides were observed in several types of cancer, including breast cancer, leukemia, gastric cancer and oral cancer (Table II).

The mtDNA D-loop contains three hypervariable segments: HVI (16024-16383), HVII (57-372) and HVIII (438-574), which are highly polymorphic $(18,62,63)$. In the present study, the most frequent D-loop mutation was in the HVII segment, particularly in a polycytosine (poly-C) mononucleotide repeat tract located between nucleotides 303 and 315, termed D310 $(55,64,65)$. The present findings confirm the previous observation that base deletions or insertions in D310, are the most common mutations of mtDNA in human cancer, including brain cancer $(55,59,65)$. The D-loop was reported to be more sensitive to oxidative stress than other mtDNA regions (66). Damage in poly-C sequences by extensive oxidative stress may lead to slippage and/or misincorporation during the replication or repair of mtDNA by mitochondrial DNA polymerase $\gamma$, and subsequently give rise to mtDNA mutations in cancer cells (67).

In the present study, four mutations were identified in the D-loop, including $176 \mathrm{~A}$-deletion (in 2 cases), 476C $>\mathrm{A}$ (in 1 case), 566C $>\mathrm{A}$ (in 1 case) and 16,405 A-deletion (in 1 case), which have not previously been reported in MITOMAP databases, and they were considered to be novel mutations in the mtDNA D-loop.

In the present study, 210 germline nucleotide changes were identified in peripheral blood and tumor tissue samples of patient cohort. All of these changes were considered to be polymorphisms. Polymorphisms in $263 \mathrm{~A}>\mathrm{G}, 16189 \mathrm{~T}>\mathrm{C}$, $16261 \mathrm{C}>\mathrm{T}$ and $16271 \mathrm{~T}>\mathrm{C}$ were the most frequently observed in the present study. Yacoubi Loueslati et al (68) determined that Tunisian female patients who harbored a 263A $>$ G germline polymorphism exhibited a weak protective effect against breast cancer risk. Previously, attention has been paid to the carriers of the 16189T $>$ C polymorphism in oncological studies, due to their susceptibility to endometrial cancer progression (69-71). The 16189T>C polymorphism has been hypothesized to affect mtDNA replication and its cellular copy number (72). In addition to endometrial cancer, the $16189 \mathrm{~T}>\mathrm{C}$ polymorphism has been identified in pilocytic astrocytoma (32), breast cancer $(26,73)$ and coronary artery disease (74). Thus far, no strong association between these polymorphisms and the etiology of brain tumors has been observed.

By analyzing the association between D-loop mutational status and clinicopathological characteristics, no significant difference was observed between the D-loop mutation group and the non-mutation group with regard to age, gender, race and histological tumor type. However, it was suggested that these mtDNA D-loop mutations are capable of initiating and promoting tumorigenesis in the brain.

As only a limited number of studies have analyzed the role of mtDNA mutations in brain tumors, it remains unclear whether the mtDNA mutation has prognostic value. In a prior study, Montanini et al (59) reported that mtDNA mutations have no prognostic effect in gliomas. Similarly, Vidone et al (75) suggested that mtDNA genotyping may not be an efficient molecular tool to predict prognosis. There is still controversy regarding the precise prognostic role of mtDNA alterations in brain tumors $(30,59,75)$. Additional studies with larger populations are required to clarify the prognostic impact of the mtDNA alteration status in brain tumors. 
Table IV. Clinicopathological characteristics of patients with brain tumors and D-Loop mutation status.

D-loop status, n $(\%)$

\begin{tabular}{|c|c|c|c|c|}
\hline \multirow{2}{*}{ Parameter } & \\
\hline & Total patients, no. (\%) & Mutation & No mutation & P-value \\
\hline No. of patients & $49(100)$ & $25(51.0)$ & $24(49.0)$ & \\
\hline \multicolumn{5}{|l|}{ Sex } \\
\hline Male & $29(59.2)$ & $15(51.7)$ & $14(48.3)$ & \multirow[t]{2}{*}{1.000} \\
\hline Female & $20(40.8)$ & $10(50.0)$ & $10(50.0)$ & \\
\hline \multicolumn{5}{|l|}{ Age, years } \\
\hline$<45$ & $20(40.8)$ & $7(35.0)$ & $13(65.0)$ & \multirow[t]{2}{*}{0.0845} \\
\hline$\geq 45$ & $29(59.2)$ & $18(62.1)$ & $11(37.9)$ & \\
\hline \multicolumn{5}{|l|}{ Ethnicity } \\
\hline Malaysian & $42(85.7)$ & $22(52.4)$ & $20(47.6)$ & \multirow[t]{3}{*}{0.8716} \\
\hline Chinese & $5(10.2)$ & $2(40.0)$ & $3(60.0)$ & \\
\hline Indian & $2(4.1)$ & $1(50.0)$ & $1(50.0)$ & \\
\hline \multicolumn{5}{|l|}{ Histological tumor types (grade) } \\
\hline Pilocytic astrocytoma (I) & $6(12.2)$ & $2(33.3)$ & $4(66.7)$ & \multirow[t]{7}{*}{0.1282} \\
\hline Astrocytomas (II) & $2(4.1)$ & $0(0)$ & $2(100)$ & \\
\hline Anaplastic astrocytomas (III) & $5(10.2)$ & $2(40.0)$ & $3(60.0)$ & \\
\hline Glioblastomas multiform (IV) & $16(32.7)$ & $12(75.0)$ & $4(25.0)$ & \\
\hline Ependymoma & $2(4.1)$ & $1(50.0)$ & $1(50.0)$ & \\
\hline Oligodendroglioma & $3(6.1)$ & $0(0)$ & $3(100)$ & \\
\hline Meningioma (I) & $15(30.6)$ & $8(53.3)$ & $7(46.7)$ & \\
\hline
\end{tabular}

In summary, the present study identified a high frequency of D-loop region mtDNA mutations in Malaysian patients with brain tumors. Although no significant association was observed between mtDNA mutations and clinicopathological parameters, the present study is able to provided novel data (local data as well as global data) of an association between mtDNA mutations and the pathogenesis of brain tumors. This may also provide important information as to how mtDNA defects lead to cancer. The alterations of mtDNA in tumorigenesis may be used in the future as novel potential target biomarkers for the diagnosis, prognosis and treatment of brain tumors.

\section{Acknowledgements}

The present study was financially supported by a Short Term Grant (grant no. 304/PPSP/61310010) from the Universiti Sains Malaysia.

\section{References}

1. Ward E, DeSantis C, Robbins A, Kohler B and Jemal A: Childhood and adolescent cancer statistics, 2014. CA Cancer J Clin 64: 83-103, 2014

2. Cancer Facts \& Figures.2017 from the American Cancer Society (https://www.cancer.org/content/dam/cancer-org/ research/cancer-facts-and-statistics/annual-cancer-facts-and-fig ures/2017/cancer-facts-and-figures-2017.pdf).

3. Siegel RL, Miller KD and Jemal A: Cancer Statistics, 2017. CA Cancer J Clin 67: 7-30, 2017.

4. Lim CC, Yahya H and Lim TO: Second report of the national cancer registry, cancer incidence in Malaysia. Kuala Lumpur, National Cancer Registry, 2003.
5. Lim CC, Rampal S, Halimah Y and Har YC: Cancer incidence in Peninsular Malaysia. Kuala Lumpur, National Cancer Registry: 2003-2005, 2008.

6. Goh CH, Lu YY, Lau BL, Oy J, Lee HK, Liew D and Wong A: Brain and spinal tumour. Med J Malaysia 69: 261-267, 2014.

7. McConigley R, Halkett G, Lobb E and Nowak A: Caring for someone with high-grade glioma: A time of rapid change for caregivers. Palliat Med 24: 473-479, 2010.

8. Visser O, Ardanaz E, Botta L, Sant M, Tavilla A and Minicozzi P; EUROCARE-5 Working Group: Survival of adults with primary malignant brain tumours in Europe; Results of the EUROCARE-5 study. Eur J Cancer: Sep 5, 2015.

9. Krishnan KJ and Turnbull DM: Mitochondrial DNA and genetic disease. Essays Biochem 47: 139-151, 2010.

10. Wang X: The expanding role of mitochondria in apoptosis. Genes Dev 15: 2922-2933, 2001.

11. Wallace DC, Fan W and Procaccio V: Mitochondrial energetic and therapeutics. Annu Rev Pathol 5: 297-348, 2010.

12. Anderson S, Bankier AT, Barrell BG, de Bruijn MH, Coulson AR, Drouin J, Eperon IC, Nierlich DP, Roe BA, Sanger F, et al: Sequence and organization of the human mitochondrial genome. Nature 290: 457-465, 1981.

13. Li H, Liu D, Lu J and Bai Y: Physiology and pathophysiology of mitochondrial DNA. Adv Exp Med Biol 942: 39-51, 2012.

14. Andrews RM, Kubacka I, Chinnery PF, Lightowlers RN, Turnbull DM and Howell N: Reanalysis and revision of the Cambridge reference sequence for human mitochondrial DNA. Nat Genet 23: 147, 1999.

15. Larsen NB, Rasmussen M and Rasmussen LJ: Nuclear and mitochondrial DNA repair: Similar pathways? Mitochondrion 5: 89-108, 2005.

16. Alexeyev M, Shokolenko I, Wilson G and LeDoux S: The maintenance of mitochondrial DNA integrity-critical analysis and update. Cold Spring Harb Perspect Biol 5: a012641, 2013.

17. Polyak K, Li Y, Zhu H, Lengauer C, Willson JK, Markowitz SD, Trush MA, Kinzler KW and Vogelstein B: Somatic mutations of the mitochondrial genome in human colorectal tumours. Nat Genet 20: 291-293, 1998.

18. Penta JS, Johnson FM, Wachsman JT and Copeland WC: Mitochondrial DNA in human malignancy. Mutat Res 488: 119-133, 2001. 
19. Chatterjee A, Mambo E and Sidransky D: Mitochondrial DNA mutations in human cancer. Oncogene 25: 4663-4674, 2006.

20. Tseng LM, Yin PH, Yang CW, Tsai YF, Hsu CY, Chi CW and Lee HC: Somatic mutations of the mitochondrial genome in human breast cancers. Genes Chromosomes Cancer 50: 800-811, 2011.

21. Li LH, Kang T, Chen L, Zhang W, Liao Y, Chen J and Shi Y: Detection of mitochondrial DNA mutations by high-throughput sequencing in the blood of breast cancer patients. Int $\mathbf{J}$ Mol Med 33: 77-82, 2014.

22. Hsu CC, Lee HC and Wei YH: Mitochondrial DNA alterations and mitochondrial dysfunction in the progression of hepatocellular carcinoma. World J Gastroenterol 19: 8880-8886, 2013

23. Lee HC, Huang KH, Yeh TS and Chi CW: Somatic alterations in mitochondrial DNA and mitochondrial dysfunction in gastric cancer progression. World J Gastroenterol 20: 3950-3959, 2014.

24. Fang Y, Huang J, Zhang J, Wang J, Qiao F, Chen HM and Hong ZP: Detecting the somatic mutations spectrum of Chinese lung cancer by analyzing the whole mitochondrial DNA genomes. Mitochondrial DNA 26: 56-60, 2015.

25. Sultana GN, Rahman A, Shahinuzzaman AD, Begum RA and Hossain CF: Mitochondrial DNA mutations-candidate biomarkers for breast cancer diagnosis in Bangladesh. Chin J Cancer 31: 449-454, 2012.

26. Tipirisetti NR, Govatati S, Pullari P, Malempati S, Thupurani MK, Perugu S, Guruvaiah P, Rao KL, Digumarti RR, Nallanchakravarthula $\mathrm{V}$, et al: Mitochondrial control region alterations and breast cancer risk: A study in South Indian population. PLoS One 9: e85363, 2014.

27. Mondal R, Ghosh SK, Talukdar FR and Laskar RS: Association of mitochondrial D-loop mutations with GSTM1 and GSTT1 polymorphisms in oral carcinoma: A case control study from northeast India. Oral Oncol 49: 345-353, 2013.

28. Kirches E, Krause G, Warich-Kirches M, Weis S, Schneider T, Meyer-Puttlitz B, Mawrin C and Dietzmann K: High frequency of mitochondrial DNA mutations in glioblastoma multiforme identified by direct sequence comparison to blood samples. Int J Cancer 93: 534-538, 2001.

29. Vega A, Salas A, Gamborino E, Sobrido MJ, Macaulay V and Carracedo A: mtDNA mutations in tumors of the central nervous system reflect the neutral evolution of mtDNA in populations. Oncogene 23: 1314-1320, 2004.

30. Mohamed Yusoff AA: Role of mitochondrial DNA mutations in brain tumors: A mini-review. J Cancer Res Ther 11: 535-544, 2015.

31. Louis DN, Ohgaki H, Wiestler OD, Cavenee WK, Burger PC, Jouvet A, Scheithauer BW and Kleihues P: The 2007 WHO classification of tumours of the central nervous system. Acta Neuropathol 114: 97-109, 2007

32. Lueth M, Wronski L, Giese A, Kirschner-Schwabe R, Pietsch T, von Deimling A, Henze G, Kurtz A and Driever PH: Somatic mitochondrial mutations in pilocytic astrocytoma. Cancer Genet Cytogenet 192: 30-35, 2009.

33. Fliss MS, Usadel H, Caballero OL, Wu L, Buta MR, Eleff SM, Jen J and Sidransky D: Facile detection of mitochondrial DNA mutations in tumors and bodily fluids. Science 287: 2017-2019, 2000.

34. Sharawat SK, Bakhshi R, Vishnubhatla S and Bakhshi S Mitochondrial D-loop variations in paediatric acute myeloid leukaemia: A potential prognostic marker. Br J Haematol 149: 391-398, 2010.

35. Ashtiani ZO, Heidari M, Hasheminasab SM, Ayati M and Rakhshani N: Mitochondrial D-Loop polymorphism and microsatellite instability in prostate cancer and benign hyperplasia patients. Asian Pac J Cancer Prev 13: 3863-3868, 2012.

36. Hung WY, Wu CW, Yin PH, Chang CJ, Li AF, Chi CW, Wei YH and Lee HC: Somatic mutations in mitochondrial genome and their potential roles in the progression of human gastric cancer. Biochim Biophys Acta 1800: 264-270, 2010.

37. Cai FF, Kohler C, Zhang B, Chen WJ, Barekati Z, Garritsen HS, Lenner P, Toniolo P, Zhang JJ and Zhong XY: Mutations of mitochondrial DNA as potential biomarkers in breast cancer. Anticancer Res 31: 4267-4271, 2011.

38. Lin JC, Wang CC, Jiang RS, Wang WY and Liu SA: Impact of somatic mutations in the D-loop of mitochondrial DNA on the survival of oral squamous cell carcinoma patients. PLoS One 10: e0124322, 2015

39. Kassem AM,El-Guendy N, Tantawy M, Abdelhady H,El-Ghor A and Abdel Wahab AH: Mutational hotspots in the mitochondrial D-loop region of cancerous and precancerous colorectal lesions in Egyptian patients. DNA Cell Biol 30: 899-906, 2011.
40. Bragoszewski P, Kupryjanczyk J, Bartnik E, Rachinger A and Ostrowski J: Limited clinical relevance of mitochondrial DNA mutation and gene expression analyses in ovarian cancer. BMC Cancer 8: 292, 2008

41. Rahmani B, Azimi C, Omranipour R, Raoofian R, Zendehdel K, Saee-Rad S and Heidari M: Mutation screening in the mitochondrial D-loop region of tumoral and non-tumoral breast cancer in Iranian patients. Acta Med Iran 50: 447-453, 2012.

42. Yacoub HA, Mahmoud WM, El-Baz HA, Eid OM, ELfayoumi RI, Elhamidy SM and Mahmoud MM: Novel mutations in the displacement loop of mitochondrial DNA are associated with acute lymphoblastic leukemia: A genetic sequencing study. Asian Pac J Cancer Prev 15: 9283-9289, 2014.

43. Pang LJ, Shao JY, Liang XM, Xia YF and Zeng YX: Mitochondrial DNA somatic mutations are frequent in nasopharyngeal carcinoma. Cancer Biol Ther 7: 198-207, 2008

44. Yu M, Shi Y, Zhang F, Zhou Y, Yang Y, Wei X, Zhang L and Niu R: Sequence variations of mitochondrial DNA D-loop region are highly frequent events in familial breast cancer. J Biomed Sci 15: 535-543, 2008

45. Chen JZ, Gokden N, Greene GF, Mukunyadzi P and Kadlubar FF: Extensive somatic mitochondrial mutations in primary prostate cancer using laser capture microdissection. Cancer Res 62: 6470-6474, 2002

46. Sharma H, Singh A, Sharma C, Jain SK and Singh N: Mutations in the mitochondrial DNA D-loop region are frequent in cervical cancer. Cancer Cell Int 5: 34, 2005.

47. Van Trappen PO, Cullup T, Troke R, Swann D, Shepherd JH, Jacobs IJ, Gayther SA and Mein CA: Somatic mitochondrial DNA mutations in primary and metastatic ovarian cancer. Gynecol Oncol 104: 129-133, 2007.

48. Prior SL, Griffiths AP, Baxter JM, Baxter PW, Hodder SC, Silvester KC and Lewis PD: Mitochondrial DNA mutations in oral squamous cell carcinoma. Carcinogenesis 27: 945-950, 2006.

49. Tan DJ, Chang J, Chen WL, Agress LJ, Yeh KT, Wang B and Wong LJ: Somatic mitochondrial DNA mutations in oral cancer of betel quid chewers. Ann N Y Acad Sci 1011: 310-316, 2004.

50. Guo W, Yang D, Xu H, Zhang Y, Huang J, Yang Z, Chen X and Huang Z: Mutations in the D-loop region and increased copy number of mitochondrial DNA in human laryngeal squamous cell carcinoma. Mol Biol Rep 40: 13-20, 2013.

51. Czarnecka AM and Bartnik E: The role of the mitochondrial genome in ageing and carcinogenesis. J Aging Res 2011: 136435, 2011.

52. Wallace DC: Mitochondria and cancer. Nat Rev Cancer 12: 685-698, 2012

53. Verschoor ML, Ungard R, Harbottle A, Jakupciak JP, Parr RL and Singh G: Mitochondria and cancer: Past, present, and future. Biomed Res Int 2013: 612369, 2013.

54. Carew JS, Zhou Y, Albitar M, Carew JD, Keating MJ and Huang P: Mitochondrial DNA mutations in primary leukemia cells after chemotherapy: Clinical significance and therapeutic implications. Leukemia 17: 1437-1447, 2003.

55. Sanchez-Cespedes M, Parrella P, Nomoto S, Cohen D, Xiao Y, Esteller M, Jeronimo C, Jordan RC, Nicol T, Koch WM, et al: Identification of a mononucleotide repeat as a major target for mitochondrial DNA alterations in human tumors. Cancer Res 61: 7015-7019, 2001

56. Rosson D and Keshgegian AA: Frequent mutations in the mitochondrial control region DNA in breast tissue. Cancer Lett 215: 89-94, 2004.

57. Lièvre A, Chapusot C, Bouvier AM, Zinzindohoué F, Piard F, Roignot P, Arnould L, Beaune P, Faivre J and Laurent-Puig P. Clinical value of mitochondrial mutations in colorectal cancer. J Clin Oncol 23: 3517-3525, 2005.

58. Choi SJ, Kim SH, Kang HY, Lee J, Bhak JH, Sohn I, Jung SH, Choi YS, Kim HK, Han J, et al: Mutational hotspots in the mitochondrial genome of lung cancer. Biochem Biophys Res Commun 407: 23-27, 2011.

59. Montanini L, Regna-Gladin C, Eoli M, Albarosa R, Carrara F, Zeviani M, Bruzzone MG, Broggi G, Boiardi A and Finocchiaro G: Instability of mitochondrial DNA and MRI and clinical correlations in malignant gliomas. J Neurooncol 74 87-89, 2005.

60. Kurtz A, Lueth M, Kluwe L, Zhang T, Foster R, Mautner VF, Hartmann M, Tan DJ, Martuza RL, Friedrich RE, et al: Somatic mitochondrial DNA mutations in neurofibromatosis type 1-associated tumors. Mol Cancer Res 2: 433-441, 2004. 
61. Lueth M, von Deimling A, Pietsch T, Wong LJ, Kurtz A, Henze G and Driever PH: Medulloblastoma harbor somatic mitochondrial DNA mutations in the D-loop region. J Pediatr Hematol Oncol 32: 156-159, 2010.

62. Lutz S, Wittig H, Weisser HJ, Heizmann J, Junge A, Dimo-Simonin N, Parson W, Edelmann J, Anslinger K, Jung S and Augustin C: Is it possible to differentiate mtDNA by means of HVIII in samples that cannot be distinguished by sequencing the HVI and HVII regions? Forensic Sci Int 113: 97-101, 2000.

63. Imaizumi K, Parsons TJ, Yoshino $M$ and Holland MM: A new database of mitochondrial DNA hypervariable regions I and II sequences from 162 Japanese individuals. Int J Legal Med 116: 68-73, 2002.

64. Parrella P, Seripa D, Matera MG, Rabitti C, Rinaldi M, Mazzarelli $\mathrm{P}$, Gravina C, Gallucci M, Altomare V, Flammia G, et al Mutations of the D310 mitochondrial mononucleotide repeat in primary tumors and cytological specimens. Cancer Lett 190: 73-77, 2003.

65. Alhomidi MA, Vedicherla B, Movva S, Rao PK, Ahuja YR and Hasan Q: Mitochondrial D310 instability in Asian Indian breast cancer patients. Tumour Biol 34: 2427-2432, 2013.

66. Mamba E, Gao X, Cohen Y, Guo Z, Talalay P and Sidransky D: Electrophile and oxidant damage of mitochondrial DNA leading to rapid evolution of homoplasmic mutations. Proc Natl Acad Sci USA 100: 1838-1843, 2003.

67. Graziewicz MA, Day BJ and Copeland WC: The mitochondrial DNA polymerase as a target of oxidative damage. Nucleic Acids Res 30: 2817-2824, 2002

68. Yacoubi Loueslati B, Troudi W, Cherni L, Rhomdhane KB and Mota-Vieira L: Germline HVR-II mitochondrial polymorphisms associated with breast cancer in Tunisian women. Genet Mol Res 9: 1690-1700, 2010.
69. Liu VW, Wang Y, Yang HJ, Tsang PC, Ng TY, Wong LC, Nagley P and Ngan H: Mitochondrial DNA variant 16189 T $>C$ is associated with susceptibility to endometrial cancer. Hum Mutat 22: 173-174, 2003.

70. Czarnecka AM, Klemba A, Semczuk A, Plak K, Marzec B, Krawczyk T, Kofler B, Golik P and Bartnik E: Common mitochondrial polymorphisms as risk factor for endometrial cancer. Int Arch Med 2: 33, 2009.

71. Cho S, Lee YM, Choi YS, Yang HI, Jeon YE, Lee KE, Lim K, Kim HY, Seo SK and Lee BS: Mitochondria DNA polymorphisms are associated with susceptibility to endometriosis. DNA Cell Biol 31: 317-322, 2012.

72. Liou CW, Lin TK, Chen JB, Tiao MM, Weng SW, Chen SD, Chuang YC, Chuang JH and Wang PW: Association between a common mitochondrial DNA D-loop polycytosine variant and alteration of mitochondrial copy number in human peripheral blood cells. J Med Genet 47: 723-728, 2010.

73. Czarnecka AM, Krawczyk T, Plak K, Klemba A, Zdrozny M, Arnold RS, Kofler B, Golik P, Szybinska A, Lubinski J, et al: Mitochondrial genotype and breast cancer predisposition. Oncol Rep 24: 1521-1534, 2010.

74. Mueller EE, Eder W, Ebner S, Schwaiger E, Santic D, Kreindl T, Stanger O, Paulweber B, Iglseder B, Oberkofler H, et al: The mitochondrial T16189C polymorphism is associated with coronary artery disease in Middle European populations. PLoS One 6: e16455, 2011.

75. Vidone M, Clima R, Santorsola M, Calabrese C, Girolimetti G, Kurelac I, Amato LB, Iommarini L, Trevisan E, Leone M, et al: A comprehensive characterization of mitochondrial DNA mutations in glioblastoma multiforme. Int J Biochem Cell Biol 63: 46-54, 2015. 